\title{
Conscientious Women: The Dispositional Conditions of Institutional Treatment on Civic
}

\section{Involvement}

Amanda Friesen

Indiana University-Purdue University Indianapolis

Paul A. Djupe

Denison University

\begin{abstract}
Current thinking about the effect of religion on civic engagement centers on “institutional treatment" - the development of resources, social pathways to recruitment, and motivation that occurs in small groups and activities of congregations. None of this work has yet incorporated the personality traits that may shape the uptake of institutional treatment. Following a growing line of research articulating how individual predispositions condition political involvement, we argue that gendered personality differences may moderate civic skill development. With new data, we find that women do not develop skills from religious involvement at the same rate as men and that this pattern is largely attributable to their distinctive personality profile. The results shift the balance between individuals and institutional influences by augmenting the cognitive bases for acquiring church-gained experiences and linking them to the public square.
\end{abstract}

\section{Forthcoming in Gender \& Politics}

This is the author's manuscript of the article to be published in final edited form at:

Friesen, A., \& Djupe, P. A. (2016). Conscientious Women: The Dispositional Conditions of Institutional Treatment on Civic Involvement. Politics \& Gender. http://doi.org/10.1017/S1743923X16000088 
Although women's participation in the workplace and society has continued to increase and educational attainment has reached parity, a gender gap persists in the acquisition of participatory resources (Djupe, Sokhey, and Gilbert 2007; Lewis-Beck et al. 2008; Sapiro 2006; Verba, Schlozman, and Brady 1995). In one strand of the literature, "institutional treatment" captures the sense that involvement in social organizations structures participatory resources, motivations, and recruitment that together sustain the gender gap (Burns, Schlozman, and Verba 2001; Djupe, Sokhey, and Gilbert 2007; Sigel 1996). However, before we can confidently ascribe institutional blame, we must assess whether predispositions condition how individuals interface with institutions in ways that may undermine the acquisition of participatory resources.

On their face, religious organizations appear to be the great equalizers of American society. Participation in them is still deep and spread throughout society, congregations generally provide opportunities to participate in governance and organizational leadership, and most promote political engagement while fewer sponsor their own forays into political action (Beyerlein and Chaves 2003; Djupe and Gilbert 2009; Schwadel 2005; Verba, Schlozman, and Brady 1995; Wald and Calhoun-Brown 2007). Because women participate in institutional religion at greater rates than men (Burns, Schlozman, and Verba 2001; Fowler et al. 2004; Putnam and Campbell 2010), congregations would seem the ideal institution to help close the gender gap in civic engagement. However, just as marriage and children generate capital for men more than for women (Burns, Schlozman, and Verba 2001; Sapiro 2006) and political knowledge levels disproportionately affect women over men (Ondercin and Jones-White 2011), churches are turning out civically prepared and recruited male congregants at greater rates than females (Calhoun-Brown 2010; Djupe and Olson 2013; Djupe, Sokhey, and Gilbert 2007). 
Indeed, "just because religion is, in this sense, a feminine sphere does not mean that it is a feminist sphere" (Putnam and Campbell 2010, 233).

Following a growing line of research articulating how individual predispositions condition political engagement (Gerber et al. 2011; Mondak 2010; Mondak and Halperin 2008), we argue that gendered personality differences may moderate civic skill development stemming from religious involvement. This line of argument dovetails with a growing consensus that religiosity is a function of individual and institutional effects that lead to gendered differences (Bradshaw and Ellison 2009; Sullins 2006). Using an integrated model that assesses resource development as a function of institutional involvement conditional on individual personality traits, our results suggest that women's personality profiles affect their religious involvement in ways that have consequences for their civic engagement. Specifically, following Mondak's (2010) argument about how conscientiousness affects political activism, women in churches are more likely to channel their conscientiousness into religious activity that is less likely to include leadership and skill development. Though the focus of the current study is the development of civic skills, it is important to note that skills deficits are critical in maintaining the gender gap in political participation (Burns, Schlozman, and Verba 2001).

\section{AN INTEGRATED MODEL}

Institutional effects and individual dispositions have sustained the focus of social scientists for decades in efforts to understand civic engagement. Rational choice, institutional barriers, groupand individual-level characteristics, social network influences, and a host of other internal and external factors have been used to model why individuals participate in the public sphere (for a review see, e.g., Leighley 1995). Many of these theories have been applied to understanding the 
persistent lag in female interest and participation in politics specifically. The well-established connections between available resources, psychological engagement, and political involvement offer the most theoretical coverage of the gender gap (Burns, Schlozman, and Verba 2001; Lewis-Beck et al. 2008; Verba, Schlozman, and Brady 1995). If socioeconomic status (SES) is the largest predictor of political involvement, then it is no surprise that the SES gender gap translates into differences in participation rates (Burns, Schlozman, and Verba 2001; Verba, Schlozman, and Brady 1995). Furthermore, women are disproportionately harmed by SES—low levels of education depress female voter turnout at a higher rate than for men (Lewis-Beck et al. 2008) — suggesting that institutional or environmental factors are interacting with demographic differences.

The same tensions can be found in how involvement in civil society affects political activity differently for women than men. In attempting to explain how SES, family, and other factors exert influence on participation, research has shown that individuals build social capital that generates a sense of connectedness to one's community and the acquisition of civic skills or resources that can lead to political engagement (Friesen 2013; Putnam 2000; Sapiro 2006). Subsequent research has focused, in part, on the institutional dynamics that enable civic skill acquisition. If SES differences tend to be persistent and difficult to overcome, then it is fortunate that organizational involvement can help subsidize citizenship and make up for the civic training that higher education would otherwise supply. In the American context, involvement in religious institutions is widespread and one of the largest contributors to the development of individual civic skills (Djupe, Sokhey, and Gilbert 2007; Lim and Putnam 2010; Smidt et al. 2003; Verba, Schlozman, and Brady 1995). Houses of worship often have extensive small groups and governance groups that allow some individuals to exercise leadership functions that are 
analogous to engaging in the political process (Djupe and Grant 2001; Leege 1988; Peterson 1992; Schwadel 2005), though the relationship between church involvement and civic skill development is not uniform across religious traditions (Wuthnow 1999).

While Verba, Schlozman, and Brady (1995) argue that religious involvement is the great equalizer of civic skill development, others are less sanguine, showing that the democratic process operates in the selection of leadership in churches. That is, political and social minorities in houses of worship are selected for organizational leadership at lower rates, a pattern that especially undercuts the representation of women (Djupe, Sokhey, and Gilbert 2007). Specifically, men practice more civic skills than women in religious settings despite participating in religious groups outside worship at lower rates. This appears to be a classic case of institutional treatment: selection mechanisms endemic to religious institutions limit the leadership development of women. Djupe and Olson (2013) reinforce this conclusion by showing that women are more likely to practice a civic skill when a woman occupies the pulpit, and they go on to open up a positive gender gap in political participation over men in such settings.

It is also possible that individual predispositions affect whether civic skill-generating activities are sought out in the first place. Specifically, we argue that differences in personality affect the rate at which men and women use their religious involvement to acquire civic skills. We focus our attention on the conditional effects of conscientiousness, one of the "Big Five" personality factors, but this should be seen as part of a broader research agenda on how gender intersects with predispositions to affect civic engagement.

In one strand of that agenda, there is already good evidence to suggest that men and women have different dispositions toward politics that govern their political styles, though these 
are not generally independent of resources. Women are more conflict avoidant, and political disagreement adversely affects their participation (Brooks 2010; Mutz 2002; Ulbig and Funk 1999; but see Djupe, McClurg, and Sokhey forthcoming). In addition, women exhibit lower levels of political knowledge, interest, and efficacy (Burns, Schlozman, and Verba 2001). Just as there is no gender gap in participation at high levels of education (Lewis-Beck et al. 2008), women with a high level of political knowledge actually are more likely than men at the same level to participate in certain political activities (Ondercin and Jones-White 2011). Again, women are disproportionately harmed (compared with men) when they exhibit low levels of knowledge. The disparity has been ascribed to "women hold[ing] themselves to a higher standard before engaging in political activities" (Ondercin and Jones-White 2011, 674).

The other strand that is central to our argument examines the link between personality and civic involvement. Leveraging the Big Five personality trait scheme, political scientists have identified many relationships between our variables of interest and the traits of openness, conscientiousness, extraversion, agreeableness, and neuroticism (or emotional stability) (Gerber et al. 2011; Mondak 2010; Mondak and Halperin 2008; Mondak et al. 2010). The most consistent personality findings regarding political participation have been that those with higher levels of openness are interested in "novel" experiences and will seek more political information, leading to higher levels of engagement, and that individuals with higher levels of extraversion will do the same if the activities in question are of a social nature (Gerber et al. 2011; Mondak 2010; Mondak and Halperin 2008; Mondak et al. 2010). Relationships with the other three traits are less clear-associations between participation and agreeableness and emotional stability are inconsistent and often dependent on the mode of participation (Gerber et al. 2011). 
Conscientiousness - measured by notions of "responsibility" and "self-control" (Roberts et al. 2005)— - has been linked to more political involvement if individuals classify such engagement as an obligation. If political involvement is valued among those individuals higher in conscientiousness, then they are more likely to participate in politics (Mondak 2010; Mondak et al. 2010). We extend this argument back one layer. For a variety of possible reasons, women are more religious and participate more in religious organizations (Flere 2007; Francis 1997), possibly because of higher levels of risk aversion than men (Miller and Stark 2002). Interestingly, risk aversion has also been linked to higher levels of conscientiousness (see Arthur and Graziano 1996; Hopwood et al. 2007; Martin, Friedman, and Schwartz 2007). This pattern in the literature, then, is suggestive that women understand conscientiousness as more likely to entail "private sphere" responsibilities, including religious life, rather than public leadership (e.g., Elshtain 1981).

Some scholars have tied women's higher religiosity to their lack of access to organizational leadership positions and resources in conservative Protestant churches (Hoffmann and Bartkowski 2008). They suggest women's veneration of biblical authority creates a "compensatory effect" whereby they are able to display their personal devotion to a "key schema of their faith" even if they are shut out of formal roles (Hoffmann and Bartkowski 2008, 1251). Our argument is somewhat different — that women high in conscientiousness understand their obligations differently and thus display higher levels of religiosity compared with men or women lower in conscientiousness. While this may be a legacy of being shut out of leadership roles, access to leadership may not bear on the relationship between conscientiousness and religiosity among women now, a point that we discuss further in our concluding section. 
Finding support for our argument depends on establishing two relationships. First, conscientiousness needs to be found to entail more religious responsibilities for women than for men. Thus, our first order of business will be to establish that conscientiousness is more tightly linked to religious guidance and attendance for women than for men. Second, and the key test, is whether higher conscientiousness weakens the relationship of church activity to practicing a civic skill among women relative to men.

\section{DATA AND DESIGN}

The data come from a national survey of 412 randomly chosen respondents using the Qualtrics web interface and data collection service. The survey spanned February 15-17, 2012, and had a gender quota of $50 \%$ of each male and female, which matches the distribution in the United States. The sample is somewhat more white than the nation ( $81 \%$ compared to $76 \%$ of all Americans, a few of whom may have chosen another race as well). Just over 7\% identified each as black and Hispanic. The average age of respondents was 47, which matches the average age of adults over 18 in the United States. The Pew Research Center (2012) reports 38\% independent (including independents who lean; $12 \%$ pure independent), 32\% Democratic (48 with leaners), and $24 \%$ Republican ( $40 \%$ with leaners) in 2012 . Our sample is $31 \%$ pure independent, $38 \%$ Democratic (including leaners), and 32\% Republican (including leaners)—our distribution comes from a single partisanship question and not the traditional branched construction. Thus, aside from partisanship, the sample reasonably resembles the 2010 United States.

\section{Dependent Variables}

We focus on three dependent variables: religious guidance, church attendance, and civic skills practiced. The first is measured with a common question, "How much guidance does religion provide you in your daily life?" It is coded 1 = no guidance at all, $2=$ some guidance, $3=$ quite a 
bit of guidance, and $4=$ a great deal of guidance. The second question asks, "Lots of things come up that keep people from attending religious services even if they want to. Thinking about your life these days, how often do you attend religious services, not including occasional weddings, baptisms or funerals?" It is coded from 1 (never) to 6 (every week or more often). The last, civic skills, is gathered by asking whether the respondent had completed any of six organizational activities in the past year as part of a group or organization, in a job, or in school: write a letter, give a speech or presentation, plan a meeting, study an issue with a group, discuss an issue with a group, and hold a leadership position (thus ranging from 0 to 6 ). In all, $48 \%$ reported exercising at least one skill, $11 \%$ more than two skills. The sample mean was 0.87 skill.

\section{Personality}

The personality battery was modeled on Mondak's (2010) implementation of a semantic differential (bipolar) approach, which some research suggests is especially valuable when the Big Five are measured with few items (Woods and Hampson 2005). Five pairs of words were used to anchor endpoints on a seven-point scale for four dimensions of the Big Five: openness to experience, conscientiousness, extraversion, and agreeableness. The instrument left out neuroticism, as Mondak found that it correlated with very few civic engagement variables. The specific pairs of words for the four personality factors as well as all coding information can be found in the online appendix.

\section{Capturing Religion}

Research on religion and civic engagement has focused primarily on the manner and degree to which involvement in a religious organization is captured. While some research has relied on a measure of church attendance to capture involvement (e.g., Wuthnow 1999), others have shown that attendance effects on civic involvement weaken or disappear in the presence of 
organizational involvement beyond worship, especially when the practice of civic skills is incorporated (e.g., Djupe and Gilbert 2009; Schwadel 2005).

One problem with the practical application of this lesson is that the opportunity to practice skills in congregations is not distributed evenly across religious groups. While the religious economy promotes a congregational structure that encourages involvement, hierarchical governance inhibits dense governing structures in churches. Catholic churches, for instance, have less lay organizational involvement than other religious groups and hence offer fewer opportunities to practice civic skills (Djupe and Grant 2001; Verba, Schlozman, and Brady 1995). We capture religious tradition through a mixed strategy that is common in the literature. We first ask about "religious preference" and then differentiate among Protestants with an identification question that pulls out evangelicals or those who call themselves "born again." This is an approach commonly employed by Pew (see also Green 2007). Given the number of cases we have to work with, we identify six exclusive and exhaustive religious traditions: nonevangelical Protestants, evangelical Protestants, Catholics, black Protestants, other religious groups (Muslims, Jews, Hindus, and others—-because of the group's composition, this is for statistical purposes only and carries no substantive meaning), and "nones" (no religious group and atheist/agnostic/humanist).

We consider two measures that suggest an orientation of otherworldliness, that God controls their fate. The first is belief that Jesus will return to earth one day soon, which several scholars have linked to opposition to action to alleviate environmental degradation (Barker and Bearce, 2013; Guth et al. 1995). The "shadow of the future" should undermine motivation to participate in civic life as well. Likewise, a belief in providence, that God has a plan for life, may 
undermine proactive participation (Glazier 2013). These factors are akin to the negative effect of involvement in religiously conservative churches (Schwadel 2005).

The model of civic skill practice also includes measures of social communication within the church. More broadly, exposure to disagreement in social networks has been linked in some studies to lower political activity (McClurg 2006; Mutz 2002), thus the presence of disagreement in the church (according to the respondent's perception) may promote the same. Moreover, clergy often attempt to encourage the participation of their congregations in public life (Djupe and Gilbert 2003; Guth et al. 1997), and those calls to participate are at least conditionally effective (Djupe and Gilbert 2009). We expect them to be effective in boosting activity in the community.

\section{Controls}

We include a nearly standard list of demographic controls that have been linked to civic activity rates. Several variables capture the possession of civically relevant resources, including income and education, but we also include a measure of political knowledge (knowledge of what office a public figure holds) as a proxy for awareness of public affairs and public opportunities for participation (Delli Carpini and Keeter 1996; Huckfeldt 2001).

\section{RESULTS}

\section{Personality Distributions}

While research on religion and personality has grown, there are still few studies that employ relatively few measures. Importantly, the measures of religion considered are not typically appropriate for evaluating civic engagement. A few relationships between religion and personality have been identified, including positive relationships between each of the Big Five and measures of religiosity focused on the intrinsic-extrinsic-quest (IEQ) framework, though the 
effect sizes were small (Francis 2010; Hills et al. 2004; Robbins et al. 2010; Saroglou 2002). In another study of the Big Five and the IEQ framework, a positive correlation between intrinsic religiosity and agreeableness was the only significant finding (Robbins et al. 2010). ${ }^{1}$ IEQ is not the typical measurement strategy used in studies of civic engagement, which instead focus on attendance, involvement beyond worship, otherworldliness, and mobilization from church social networks. That is, the tests of the relationships between personality traits and religion have ignored most of the dimensions of religion associated with civic engagement. Though conscientiousness is the focus of our argument, it is important to start with a broader look at how the other Big Five traits manifest in our sample and with our key variables.

Thus, we begin our analysis with an examination of the four available personality dimensions by the religious tradition of the respondent, followed by the link between personality and measures of religious experience linked to civic involvement. The religious tradition results are available in Figure 1, which show that personality is not randomly distributed across these religious groupings. For each dimension, the ANOVA test for variation across the groups is significant at conventional levels (though $p=.07$ for openness). White evangelicals anchor the high end of each personality dimension and stand out clearly as the most extraverted and the most agreeable. If evangelical churches host the most accountability pressures and the greatest pressures to evangelize (e.g., Kelley 1972; Smith 1998), then the normativity of these two dimensions makes sense. Black Protestants are quite like white evangelicals except in their levels of extraversion—black Protestants post the lowest mean among included groups, which is surely a result of minority status. "Other" religious affiliates occupy the low end of the scales, with the

\footnotetext{
${ }^{1}$ Intrinsic, extrinsic, and quest are religious orientations derived from Allport and Ross (1967), with Batson's (1982) addition of quest. They specify whether the individual uses religion as a means to an end (extrinsic), whether religion specifies a set of goals to orient behavior (intrinsic), or whether religion is a means to uncover new experiences and values (quest).
} 
exception of extraversion, while religious nones closely match them except in openness, where they place quite high on the scale. The variation among groups is interesting, but the larger point is perhaps more important: there is real diversity among even these highly aggregated religious groups that may help shape their public presence. More specific to our investigation of conscientiousness, the trait appears to be highly prized among religious adherents, and there is no good evidence of a self-selection effect - that is, more conscientious individuals are not clustered in evangelical congregations, for example.

\section{[INSERT FIGURE 1 ABOUT HERE]}

Now we assess in Table 1 whether the four available personality dimensions are related to a wide range of religious variables that are relevant to civic engagement; here we split the results by gender. The first thing to note is that none of the relationships is particularly strong, with the exception of agreeableness (reflecting what we witnessed in Figure 1) and a few related to conscientiousness. More agreeableness is modestly linked to taking more religious guidance and negatively linked to several more conservative beliefs — that the devil exists, providence, and the end times. Conscientiousness has a similar pattern of results, though at weaker levels. Although generally the results for women are not much different than for men, the relationships are consistently larger for women (and hence more likely to be significant), especially for the traits of conscientiousness and agreeableness.

Of some importance to this investigation, church attendance and small group involvement are nearly orthogonal to personality traits (with no controls), with the exception that more extraverted and agreeable women attend more often and women involved with religious small groups are a bit more agreeable. It is important because without a distribution of conscientiousness among those involved, we could not sort out whether levels of the trait change 
how people channel church activity. We control for the other personality traits in the analysis that follows.

\section{[TABLE 1 ABOUT HERE]}

\section{Gendered Conscientiousness}

Essential to our explanation of why women do not practice civic skills at the same rate as men is that women tend to understand conscientiousness differently. In particular, we expect that religion is more strongly related to conscientiousness among women. ${ }^{2}$ Our purpose in this analysis is not to explain religiosity but instead to indicate that highly conscientious women see their obligations as more tightly linked to religion compared with conscientious men and compared with women with lower levels of the trait. There are surely multiple reasons for this relationship, but demonstrating a link here is essential groundwork if conscientiousness entails different effects on civic engagement for men and women.

This evidence is shown in two ways in Figure 2, through religious guidance and church attendance. ${ }^{3}$ In the top panel, religious guidance among women is significantly distinguishable from men's at the high end of the conscientiousness scale $(.8$ and higher, where the confidence intervals no longer overlap with zero). This means that conscientious women rely more on religion than conscientious men by nearly half a point (range $=4$ ). It is important to note that most women score at .8 or higher on conscientiousness (69\%) compared to a minority of men (49\%), supporting findings that women tend to score higher on this trait (Mondak 2010). ${ }^{4} \mathrm{We}$ validate this relationship in the bottom panel by using church attendance as another marker of

\footnotetext{
${ }^{2}$ The difference is assessed with an ordinary least squares regression model of religious guidance employing an interaction of gender and conscientiousness (and their main effects) with controls (results not shown).

${ }^{3}$ For the full model results, see Table A1 in the online appendix.

${ }^{4}$ While the distribution of conscientiousness among women is almost necessarily skew (with a long left tail) given the cutoff at a value of 1, it is not kurtotic (neither too peaked nor too flat). The distribution for men is not skew, but it is too flat. Thus, both distributions violate normality assumptions in one dimension, but both maintain a singlepeaked distribution and two tails.
} 
religiosity. The figure tells the same story. Women with higher conscientiousness attend church more often than men, and the effect is distinguishable beginning at the same level of conscientiousness (.8). At the highest level, women attend worship .3 point more often than men - about $5 \%$ of the scale. We take this as evidence that women tend to see conscientiousness as entailing different obligations.

\section{[INSERT FIGURE 2 HERE]}

\section{Civic Skills}

At this point, we turn to models to assess the role of personality in context of civically relevant activity. We investigate civic skill practice because skills are such an important determinant of political participation and one of the more important effects of involvement in religious institutions in the literature (e.g., Leege 1987; Verba, Schlozman, and Brady 1995; but see Djupe and Gilbert 2009; Djupe and Grant 2001). Moreover, because skills, by definition, can only be practiced in organizational settings, they are metrics of civic engagement, too. Given that most of the variation is concentrated between having one skill versus no skills, we collapse it to a binary—either the respondent exercised no skills or at least one skill in the past year. Before getting to the primary test, we wanted to confirm previous findings that women's church activity does not result in the same rate of developing skills. In a model combining men and women, we found a significant interaction between gender and church activity on skill development. Women are just over $20 \%$ less likely than men to practice a civic skill when involved in a church small group, ratifying Djupe, Sokhey, and Gilbert's (2007) finding in these data.

The estimates of practicing a skill are presented separately for men and women in Table 2. Again, the test of key interest is the interaction between conscientiousness and church small group activity, the primary location in which skills can be practiced. Our expectation is that 
conscientiousness weakens the otherwise beneficial effect of church group activity on skill development among women.

[INSERT TABLE 2 ABOUT HERE]

The results suggest that the return on religious investment for women may be limited by their personality profile. The interaction between conscientiousness and small group involvement among women is displayed in Figure 3. ${ }^{5}$ The figure shows the marginal effects from being involved in a church small group on the likelihood of practicing a skill conditional on conscientiousness (all other variables from the Table 2 model are held at their means). ${ }^{6}$ While being involved in a church small group exerts a beneficial effect on skill development, the effect decays as conscientiousness grows stronger. By a conscientiousness score of .85, affecting $47 \%$ of this sample of women, church activity exerts no statistically discernible effect on skill development. $^{7}$

\section{[INSERT FIGURE 3 HERE]}

Notably, there is no interaction of conscientiousness and church group activity affecting the civic skill practice of men. Nor is there is a direct relationship between church group activity and civic skill practice among men (or with conscientiousness). Instead, men's civic skill

\footnotetext{
${ }^{5}$ Previously, scholars would be hesitant to investigate an interaction term if the $t$-test on the interaction term reported out by a statistical package failed to dip below $p=.05$. However, that is simply a summary statistic and does not indicate the extent of the range at which the effects between groups may be distinguishable. Kam and Franzese (2007) recommend examining the full range of the interaction to show whether there is any portion of the range at which slopes are distinguishable, a strategy we employ here. We use Stata's margins and marginsplot commands to generate graphs of the interactions. For marginal effects graphs, we use $90 \%$ confidence intervals, which is a common practice.

${ }^{6}$ There could be several possible explanations for this, but the most likely are that women are overrepresented in church small groups and thus have a lower probability of being selected to exercise leadership (if gender equity is a goal), while, relatedly, men have higher status and thus "stand out" to exercise leadership (Djupe, Sokhey, and Gilbert 2007). As we have seen, women also tend to exhibit higher levels of conscientiousness and experience its implications in different ways than men that may make the exercise of leadership less attractive. The latter argument is supported here with a significant interaction between gender and conscientiousness: women with higher scores are less likely to develop a skill (not shown).

${ }^{7}$ Among the women in the sample, $47 \%$ scored at .85 or higher in conscientiousness. Limiting this to the portion that is also involved in a church small group, $12 \%$ of sample women are affected.
} 
practice in this sample is linked to their income (but not education), their extraversion, and their church attendance. Those men with a short time horizon (belief in the end times) are less likely to practice a skill, while black Protestant and secular men are more likely to practice a skill.

Outside of age —older men and women are less likely to develop a skill— these determinants vary somewhat for women. Instead of income, more education drives up skill development among women. Black Protestant women are less likely to develop a skill than Catholic women (the excluded reference), while those taking more guidance from religion are more likely to develop a skill.

Mondak (2010) argues that the effect of conscientiousness on political activity is contingent on the desirable target. While conscientiousness often entails personal responsibility and an attending degree of insularity, it may be reformulated to include a broader public responsibility. Here, as in most surveys, women have lower degrees of political engagement (such as political knowledge which is half a point lower for women) and higher attendance and reliance on religion for guidance. Thus, there is reasonable evidence to suggest that conscientiousness captures this basic difference in orientation that helps to sustain women's presence in the "private sphere." Even when women do engage in voluntary activities that have been linked consistently to civic skill development (church small groups), this personality predisposition bounds broader application of that experience.

\section{DISCUSSION: SCOPE CONDITIONS}

The effects of conscientiousness here are consequential given their location in the distribution of the trait. A majority of women score above .8 on the scale and hence fall into the range where conscientiousness exerts a discernible drag on the translation of church group activity into civic 
skill practice. About $20 \%$ in this sample scores above .9 , which is close to where church activity is estimated to have no effect on skill development.

Another way to think of the scope of the effects is to assess how they interrelate with other religious variables. One that is significant for women is religious guidance. Guidance, by itself, has quite large effects on the probability of practicing a civic skill, raising the probability from .22 for those taking no guidance at all to .57 for those taking a great deal of guidance from their faith. Figure 4 shows the interaction of interest-the marginal effect of church activity across the range of conscientiousness - across the four levels of religious guidance among women. The effect of guidance is visible here. In the upper left (no guidance), church activity has a pronounced effect among those women with low levels of conscientiousness, raising the likelihood of practicing a civic skill by .65. By the time we reach the lower right (a great deal of guidance), guidance props up the likelihood of skill practice and church activity has a much reduced effect, now only raising the likelihood of skill practice by .34 among low conscientiousness women. However, it is notable that higher conscientiousness runs the effect of church activity to zero regardless of religious guidance levels. In each case, by roughly conscientiousness equal to .8 , the effect of church activity on skill practice is indistinguishable from zero.

\section{[INSERT FIGURE 4 ABOUT HERE]}

We can also connect these findings to political participation. In models of a general political activity index, civic skills have been one of the most consistent and powerful forces (e.g., Verba, Schlozman, and Brady 1995), such that each skill boosts political activity by at least one-tenth of an activity (Verba, Schlozman, and Brady 1995, 444, 447). In this sample, civic skills are more important compared to Verba, Schlozman, and Brady's results but also vary in 
effect by gender. All else being equal, women who do not practice a skill engage in 0.7 activity, which jumps to 1.6 if they do practice a skill. Men jump from 0.9 activity if they have not practiced a skill to 1.5 political activities if they have practiced one. Anything that bears on skill development among women is especially impactful on their public presence. ${ }^{8}$

\section{CONCLUSION}

Sociologists of religion have long sought explanations of the gendered differences in religiosity between men and women, and our findings interacting individual and institutional elements may help bridge the socialization versus natural disposition theories (Bradshaw and Ellison 2009; Collett and Lizardo 2009; Miller and Stark 2002; Sullins 2006). The personality traits of conscientiousness and risk aversion and the social capital builder of religious participation have all been linked to civic engagement. We suggest that gender is an important moderating force.

Previous research has treated gender effects, demographics, personality, and church involvement independently when predicting civic engagements. We argue that an integrated model can provide valuable insights into how individuals interact with institutional-level influences to shape their broader civic investments. Specifically, civic skill development generated from religious involvement is not uniform among men and women and can be linked to different understandings of conscientiousness between the sexes. This continues to be a puzzle because women tend to be more engaged in church life, and it is the type of social context that would seem to be a comfortable place to promote women's skill development. Regarding social capital, for example, women are more likely than men to indicate having more close friends in church and to indicate that small group involvement has helped them through an emotional crisis (Wuthnow 2004), providing more evidence for notions of "private sphere" returns on investment

\footnotetext{
${ }^{8}$ For the full model results, see Table A2 in the online appendix.
} 
for women. While the extant literature has implicated institutional treatment as the culprit for the weak return in civic skills women receive from their involvement in churches (Djupe and Olson 2013; Djupe, Sokhey, and Gilbert 2007), here we elaborate that logic by finding women's personality dispositions to be an important driver of their religious investment strategy.

That logic suggests that conscientiousness plays a role in enhancing participation in what individuals value, channeling energy in a disciplined way into some activities and away from others. It is a long-standing finding that women are more religious than men (Flere 2007; Francis 1997), though there is considerable disagreement about why. The primary tension is between biological and social explanations. In one review, women seek out religion because they are more risk averse (e.g., Miller and Stark 2002), while others argue about the influence of some form of power control. For instance, Collett and Lizardo (2009) argue that women are socialized into risk aversion in patriarchal households, which drives religiosity. In another variant, women adopt more religious ideologies as a compensatory mechanism for being denied leadership positions in congregations (Hoffman and Bartkowski 2008). While we do not have an appropriate design to test the long-term socialization hypothesis, we can address the compensatory argument. In these data, men and women exercise leadership in church at the same rates and link church activity to leadership in similar amounts. If anything, religiosity is strengthened by exercising leadership. ${ }^{9}$

More conscientious women are likely to be more religious in terms of religious guidance and attendance at worship. However, once in church, more and less conscientious women are equally likely to engage in church activities beyond worship. More conscientious women are less likely to link that activity to civic skills — what is essentially leadership in community

\footnotetext{
${ }^{9}$ See the online appendix for additional results regarding these relationships on pp. 7-8.
} 
organizations. Importantly, these patterns are not limited to or especially prominent in conservative denominations. At least in these data, the effect of conscientiousness on religiosity is not conditioned on education and gender differences are not conditional on religiosity either (not shown). That is, the suggestive evidence here places more weight on disposition than it does on power control or as compensation for agency loss.

What we can say at this point is that for more conscientious women, their civic engagements more often stop at the church vestibule. While church involvement generally has a positive effect on civic skill development, more conscientiousness draws limits on its broader applicability among women. However, it has not been clear whether women seek different types of religious involvement (personal piety, social committees, Sunday school teaching) that are not as conducive to civic skill development. In part, future research should examine the interaction between specific types of involvement, and roles within that involvement, and resulting civic skill development. But for now the broader lesson is clear: men are more likely to convert religious behavior into political participation, whereas women are more likely to see religion and church life as an end in itself (e.g., Elshtain 1981). While religious institutions may not be entirely to blame for this pattern, given the reputation of houses of worship as the great equalizer of participatory resources, it is important to sort out just which of these assertions holds more water.

Amanda Friesen is Assistant Professor of Political Science and Faculty Research Fellow for the Center for the Study of Religion and American Culture at Indiana University-Purdue University Indianapolis: amfriese@iupui.edu; Paul A. Djupe is Associate Professor of Political Science at Denison University, Granville, OH: djupe@denison.edu 


\section{REFERENCES}

Allport, Gordon W., and J. Michael Ross. 1967. "Personal Religious Orientation and Prejudice." Journal of Personality and Social Psychology 5 (4): 432-43.

Arthur, Winfred, and William G. Graziano. 1996. “The Five-Factor Model, Conscientiousness, and Driving Accident Involvement." Journal of Personality 64 (3): 593-618.

Barker, David C., and David H. Bearce. 2013. "End-Times Theology, the Shadow of the Future, and Public Resistance to Addressing Global Climate Change." Political Research Quarterly 66 (2): 267-79.

Batson, Daniel. 1982. Religion and the Individual. New York: Oxford University Press.

Beyerlein, Kraig, and Mark Chaves. 2003. "The Political Activities of Religious Congregations in the United States." Journal for the Scientific Study of Religion 42 (2): 229-46.

Bradshaw, Matthew, and Christopher G. Ellison. 2009. "The Nurture-Nature Debate Is Over, and Both Sides Lost! Implications for Understanding Gender Differences in Religiosity.” Journal for the Scientific Study of Religion 48 (2): 241-51.

Brooks, Deborah J. 2010. “A Negativity Gap? Voter Gender and Attack Politics in American Elections." Politics \& Gender 6 (3): 319-41.

Burns, Nancy, Kay Lehman Schlozman, and Sidney Verba. 2001. The Private Roots of Public Action: Gender, Equality, and Political Participation. Cambridge, MA: Harvard University Press.

Calhoun-Brown, Allison. 2010. “This Far by Faith? Religion, Gender, and Efficacy.” In Religion and Democracy in the United States: Danger or Opportunity, eds. Alan Wolfe and Ira Katznelson. New York: Russell Sage, 279-307. 
Collett, Jessica L., and Omar Lizardo. 2009. “A Power-Control Theory of Gender and Religiosity.” Journal for the Scientific Study of Religion 48 (2): 213-31.

Delli Carpini, Michael X., and Scott Keeter. 1996. What Americans Know about Politics and Why It Matters. New Haven, CT: Yale University Press.

Djupe, Paul A., and Christopher P. Gilbert. 2003. The Prophetic Pulpit: Clergy, Churches, and Communities in American Politics. Lanham, MD: Rowman \& Littlefield.

. 2009. The Political Influence of Churches. New York: Cambridge University Press.

Djupe, Paul A., and J. Tobin Grant. 2001. "Religious Institutions and Political Participation in America." Journal for the Scientific Study of Religion 40 (2): 303-14.

Djupe, Paul A., Scott D. McClurg, and Anand E. Sokhey. Forthcoming. “The Political Consequences of Gender in Social Networks.” British Journal of Political Science.

Djupe, Paul A., and Laura R. Olson. 2013. "Stained-Glass Politics: Does Women's Associational Leadership Engender the Political Engagement of Women?” Politics, Groups, \& Identities 1 (3): 329-48.

Djupe, Paul A., Anand E. Sokhey, and Christopher P. Gilbert. 2007. "Present but Not Accounted For? Gender Differences in Civic Resource Acquisition.” American Journal of Political Science 51 (4): 906-20.

Elshtain, Jean B. 1981. Public Man, Private Woman: Women in Social and Political Thought. Princeton, NJ: Princeton University Press.

Flere, Sergej. 2007. “Gender and Religious Orientation.” Social Compass 54 (2): 239-53.

Fowler, Robert, Allen Hertzke, Laura Olson, and Kevin Den Dulk. 2004. Religion and Politics in America. 3rd ed. Boulder, CO: Westview Press. 
Francis, Leslie J. 1997. “The Psychology of Gender Differences in Religion: A Review of Empirical Research.” Religion 27 (1): 81-96.

—. 2010. "Personality and Religious Orientation: Shifting Sands or Firm Foundations?" Mental Health, Religion, and Culture 13(7/8): 793-803.

Friesen, Amanda. 2013. "Religion, Politics and the Social Capital of Children." Journal of Women, Politics \& Policy 34 (3): 197-218.

Gerber, Alan S., Gregory A. Huber, David Doherty, Conor M. Dowling, Connor Raso, and Shang E. Ha. 2011. "Personality Traits and Participation in Political Processes.” Journal of Politics 73 (3): 692-706.

Glazier, Rebecca A. 2013. "Divine Direction: How Providential Religious Beliefs Shape Foreign Policy Attitudes." Foreign Policy Analysis 9 (2): 127-42.

Green, John C. 2007. The Faith Factor: How Religion Influences American Elections. Westport, CT: Praeger.

Guth, James L., John C. Green, Lyman A. Kellstedt, and Corwin E. Smidt. 1995. "Faith and the Environment: Religious Beliefs and Attitudes on Environmental Policy.” American Journal of Political Science 39 (2): 364-82.

Guth, James L., John C. Green, Corwin E. Smidt, Lyman A. Kellstedt, and Margaret Poloma. 1997. The Bully Pulpit: The Politics of Protestant Clergy. Lawrence: University Press of Kansas.

Hills, Peter, Leslie J. Francis, Michael Argyle, and Chris J. Jackson. 2004. "Primary Personality Trait Correlates of Religious Practice and Orientation." Personality and Individual Differences 36 (1): 61-73. 
Hoffmann, John P., and John P. Bartkowski. 2008. “Gender, Religious Tradition, and Biblical Literalism.” Social Forces 86 (3): 1245-72.

Hopwood, Christopher J., Leslie C. Morey, Andrew E. Skodol, Robert L. Stout, Shirley Yen, Emily B. Ansell, Carlos M. Grilo, and Thomas H. McGlashan. 2007. "Five-Factor Model Personality Traits Associated with Alcohol-Related Diagnoses in a Clinical Sample.” Journal of Studies on Alcohol and Drugs 68 (3): 455-60.

Huckfeldt, Robert. 2001. "The Social Communication of Political Expertise.” American Journal of Political Science 45 (2): 425-38.

Kam, Cindy D. 2012. "Risk Attitudes and Political Participation.” American Journal of Political Science 56 (4): 817-36.

Kam, Cindy D., and Robert J. Franzese, Jr. 2007. Modeling and Interpreting Interactive Hypotheses in Regression Analysis. Ann Arbor: University of Michigan Press.

Kelley, Dean M. 1972. Why Conservative Churches Are Growing. New York: Harper \& Row. Leege, David C. 1988. "Catholics and the Civic Order: Parish Participation, Politics, and Civic Participation." Review of Politics 50 (4): 704-37.

Leege, David C. and Lyman A. Kellstedt, eds. 1993. Rediscovering the Religious Factor in American Politics. Armonk, NY: M.E. Sharpe.

Leighley, Jan E. 1995. “Attitudes, Opportunities, and Incentives: A Field Essay on Political Participation." Political Research Quarterly 48 (1): 181-209.

Lewis-Beck, Michael S., William G. Jacoby, Helmut Norpoth, and Herbert E. Weisberg. 2008. The American Voter Revisited. Ann Arbor: University of Michigan Press.

Lim, Chaeyoon, and Robert D. Putnam. 2010. "Religion, Social Networks, and Life Satisfaction.” American Sociological Review 75 (6): 914-33. 
Martin, Leslie R., Howard S. Friedman, and Joseph E. Schwartz. 2007. "Personality and Mortality Risk across the Life Span: The Importance of Conscientiousness as a Biopsychosocial Attribute.” Health Psychology 26 (4): 428-36.

McClurg, Scott D. 2006. "The Electoral Relevance of Political Talk: Examining Disagreement and Expertise Effects in Social Networks on Political Participation." American Journal of Political Science 50 (3): 737-54.

Miller, Alan, and Rodney Stark. 2002. "Gender and Religiousness: Can Socialization Explanations be Saved?" American Journal of Sociology 107 (6): 1399-1423.

Mondak, Jeffery J. 2010. Personality and the Foundations of Political Behavior. New York: Cambridge University Press.

Mondak, Jeffery J., and Karen D. Halperin. 2008. “A Framework for the Study of Personality and Political Behavior." British Journal of Political Science 38 (2): 335-62.

Mondak, Jeffrey J., Matthew V. Hibbing, Damarys Canache, Mitchell A. Seligson, and Mary R. Anderson. 2010. "Personality and Civic Engagement: An Integrative Framework for the Study of Trait Effects on Political Behavior.” American Political Science Review 104 (1): $85-110$.

Mutz, Diana C. 2002. "Cross-Cutting Social Networks: Testing Democratic Theory in Practice." American Political Science Review 96 (1): 111-26.

Ondercin, Heather L., and Daniel Jones-White. 2011. "Gender Jeopardy: What Is the Impact of Gender Differences in Political Knowledge on Political Participation?" Social Science Quarterly 92 (3): 674-94.

Peterson, Steven A. 1992. "Church Participation and Political Participation: The Spillover Effect." American Politics Quarterly 20 (1): 123-39. 
Pew Research Center. 2012. "Section 9: Trends in Party Affiliation." http://www.peoplepress.org/2012/06/04/section-9-trends-in-party-affiliation/ (accessed March 24, 2014).

Putnam, Robert D. 2000. Bowling Alone: The Collapse and Revival of American Community. New York: Simon \& Schuster.

Putnam, Robert D., and David E. Campbell. 2010. American Grace: How Religion Divides and Unites Us. New York: Simon \& Schuster.

Robbins, Mandy, Leslie Francis, David McIlroy, Rachel Clarke, and Lowri Pritchard. 2010. “Three Religious Orientations and Five Personality Factors: An Exploratory Study Among Adults in England." Mental Health, Religion \& Culture 13 (7/8): 771-75.

Roberts, Brent W., Oleksandr S. Chernyshenko, Stephen Stark, and Lewis R. Goldberg. 2005. "The Structure of Conscientiousness: An Empirical Investigation Based on Seven Major Personality Questionnaires.” Personnel Psychology 58 (1): 103-39.

Sapiro, Virginia. 2006. "Gender, Social Capital, and Politics." In Gender and Social Capital, eds. Brenda O'Neill and Elisabeth Gidengil. New York: Routledge, 151-83.

Saroglou, Vassilis. 2002. "Religion and the Five Factors of Personality: A Meta-Analytic Review." Personality and Individual Differences 32 (1): 15-25.

Schwadel, Philip. 2005. "Individual, Congregational, and Denominational Effects on Church Members' Civic Participation.” Journal for the Scientific Study of Religion 44 (2): 15971.

Sigel, Roberta S. 1996. Ambition and Accommodation: How Women View Gender Relations. Chicago: University of Chicago Press.

Smidt, Corwin, John Green, James Guth, and Lyman Kellstedt. 2003. "Religious Involvement, Social Capital, and Political Engagement: A Comparison of the United States and 
Canada." In Religion as Social Capital: Producing the Common Good, ed. Corwin Smidt. Waco, TX: Baylor University Press, 153-70.

Smith, Christian. 1998. American Evangelicalism: Embattled and Thriving. Chicago: University of Chicago Press.

Sullins, D. Paul. 2006. “Gender and Religion: Deconstructing Universality, Constructing Complexity." American Journal of Sociology 112 (3): 838-80.

Ulbig, Stacy G., and Carolyn L. Funk. 1999. "Conflict Avoidance and Political Participation.” Political Behavior 21 (3): 265-82.

Verba, Sidney, Kay Lehman Schlozman, and Henry E. Brady. 1995. Voice and Equality: Civic Voluntarism in American Politics. Cambridge, MA: Harvard University Press.

Wald, Kenneth D., and Allison Calhoun-Brown. 2007. Religion and American Politics in the United States. 5th ed. Lanham, MD: Rowman \& Littlefield.

Woods, Stephen A., and Sarah E. Hampson. 2005. "Measuring the Big 5 with Single Items Using a Bipolar Response Scale.” European Journal of Personality 19 (5): 373-90. Wuthnow, Robert. 1999. "Mobilizing Civic Engagement: The Changing Impact of Religious Involvement." In Civic Engagement in American Democracy, eds. Theda Skocpol and Morris P. Fiorina. Washington, DC: Brookings Institution Press, 331-66.

- 2004. Saving America: Faith-Based Services and the Future of Civil Society. Princeton, NJ: Princeton University Press. 
Table 1. Bivariate correlations between personality traits and religious variables, by gender

\begin{tabular}{|c|c|c|c|c|c|c|c|c|}
\hline & \multicolumn{2}{|c|}{ Openness } & \multicolumn{2}{|c|}{$\begin{array}{l}\text { Conscien- } \\
\text { tiousness }\end{array}$} & \multicolumn{2}{|c|}{ Extraversion } & \multicolumn{2}{|c|}{ Agreeableness } \\
\hline & Men & Women & Men & Women & Men & Women & Men & Women \\
\hline Worship attendance & -.09 & .08 & -.06 & .11 & .00 & $.13^{*}$ & -.02 & $.14^{*}$ \\
\hline $\begin{array}{l}\text { Small group } \\
\text { involvement }\end{array}$ & -.04 & .02 & .04 & .03 & .05 & .11 & .11 & $.12^{*}$ \\
\hline End times belief & .08 & .06 & -.02 & $-.12^{*}$ & -.08 & .02 & -.08 & $-.26 *$ \\
\hline Religious guidance & .08 & .08 & $.16^{*}$ & $.25^{*}$ & -.01 & .06 & $.19 *$ & $.30 *$ \\
\hline Devil exists & .03 & .00 & -.04 & $-.14^{*}$ & -.08 & .04 & -.08 & $-.23 *$ \\
\hline God has a plan for me & -.03 & .02 & $-.17 *$ & $-.17 *$ & -.11 & -.01 & $-.25^{*}$ & $-.30 *$ \\
\hline $\begin{array}{l}\text { Course of life is } \\
\text { directed by God }\end{array}$ & .11 & .03 & .05 & $-.15^{*}$ & -.10 & .00 & -.03 & $-.21 *$ \\
\hline Inclusive values & .07 & -.02 & $.13^{*}$ & .10 & .02 & .05 & $.24^{*}$ & $.32 *$ \\
\hline Exclusive values & $-.14 *$ & .03 & -.03 & .06 & .06 & -.02 & .05 & .11 \\
\hline $\begin{array}{l}\text { Church engaged in } \\
\text { outreach }\end{array}$ & $.12^{*}$ & .08 & .03 & $.17^{*}$ & .09 & $.16^{*}$ & $.13^{*}$ & $.19 *$ \\
\hline $\begin{array}{l}\text { Clergy encourage } \\
\text { political activity }\end{array}$ & -.02 & -.06 & .01 & .00 & .02 & .11 & -.01 & -.02 \\
\hline $\begin{array}{l}\text { People I disagree with } \\
\text { in church }\end{array}$ & -.06 & -.02 & -.02 & .04 & $.18^{*}$ & .05 & .05 & .02 \\
\hline $\begin{array}{l}\text { Attended political adult } \\
\text { education session }\end{array}$ & -.06 & $-.12^{*}$ & .00 & -.04 & .06 & .04 & -.02 & -.06 \\
\hline
\end{tabular}

Note: $* p<.10$. 
Table 2. Estimates of civic skills practiced for men and women with an interaction between church activity and conscientiousness (logit)

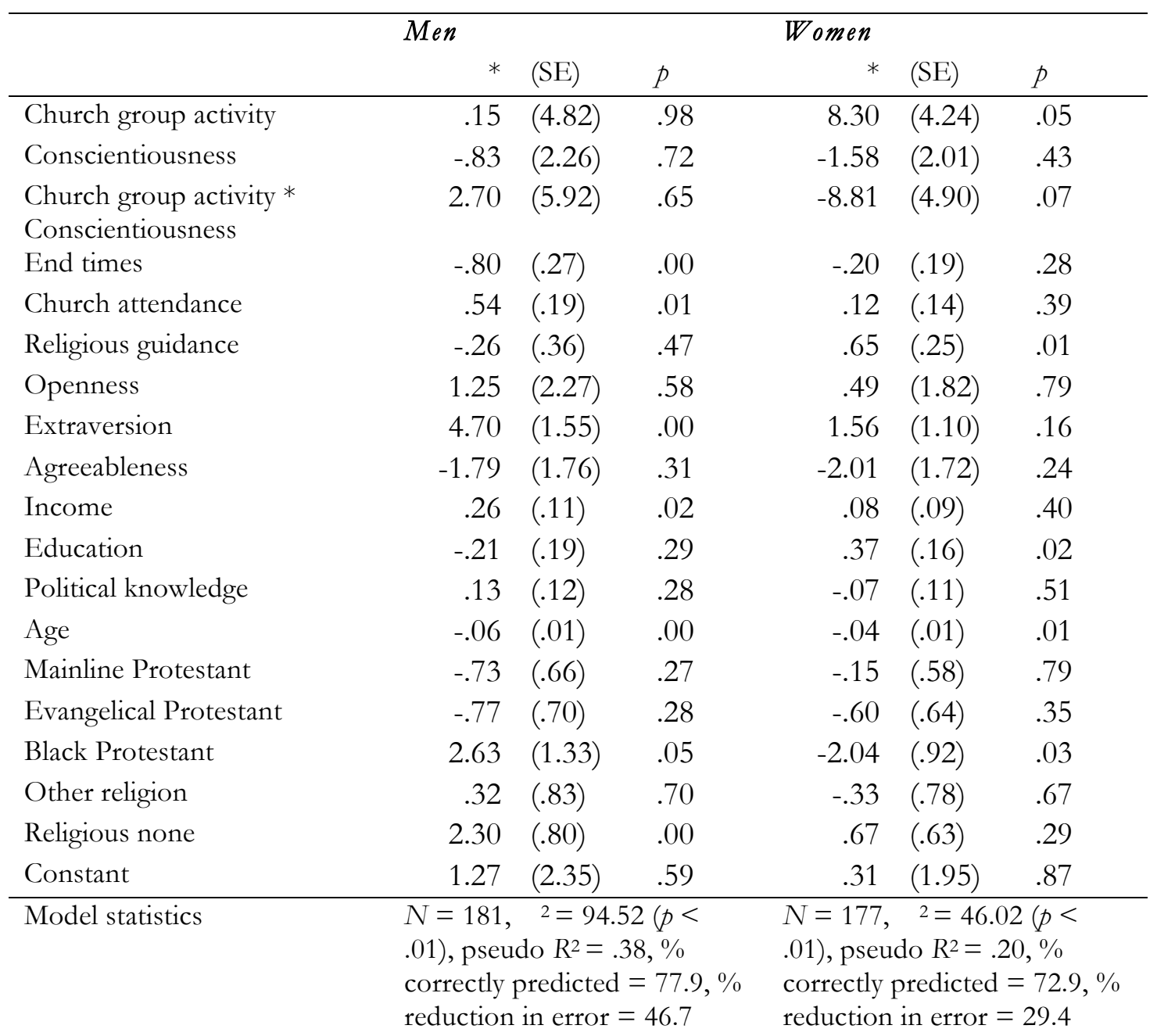

Note: Catholic is the excluded reference category. 
Figure 1-Variation in Personality Scores by Religious Tradition

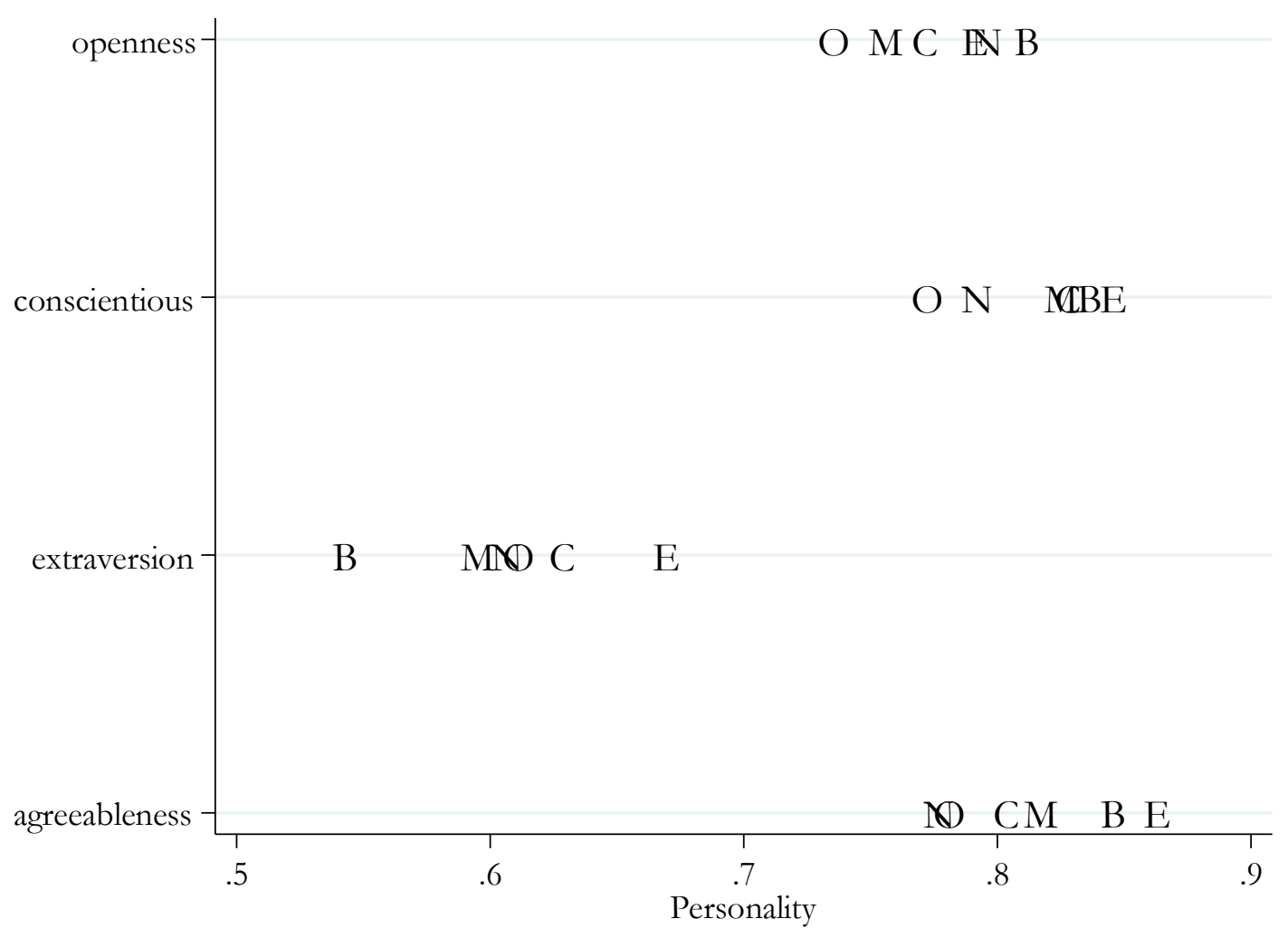

Note: $\mathrm{B}=$ black Protestant, $\mathrm{C}=$ Catholic, $\mathrm{E}=$ white Evangelical, $\mathrm{M}=$ mainline Protestant, $\mathrm{N}=$ none, $\mathrm{O}=$ other religious tradition. $N=402$. ANOVA tests for each personality dimension are significant (openness, $p=.07$; conscientiousness, $p=.02$; extraversion, $p=.01$; agreeableness, $p<$ $.01)$. 
Figure 2-Conscientious Women Rely on Religion as a Guide in Life and Attend Worship at Higher Rates than Men ( $90 \%$ confidence intervals)
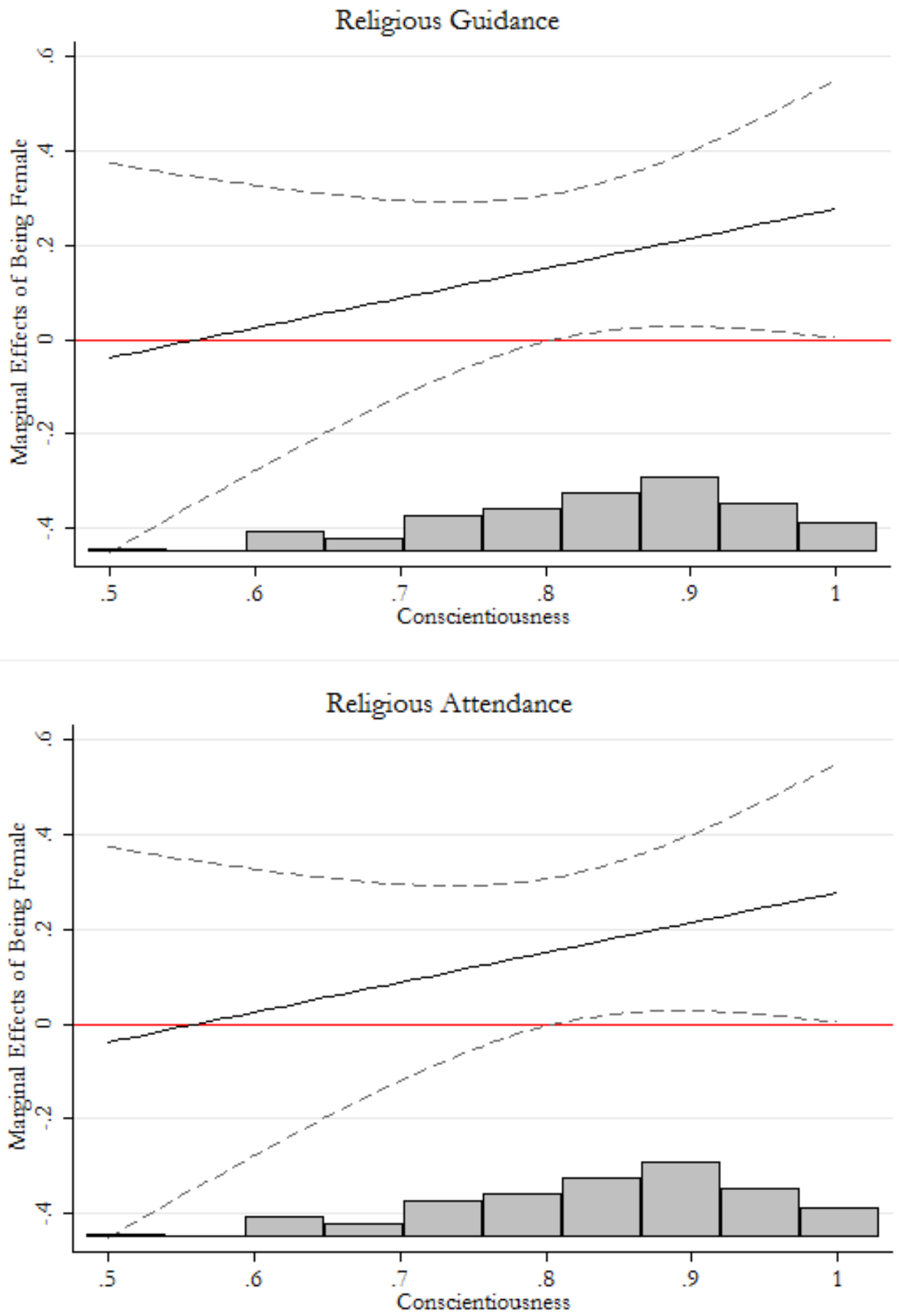

Note: Models control for religious tradition, education, and age. The histograms show the distribution of conscientiousness. 
Figure 3-The Positive Effects of Church Small Group Involvement on Civic Skill Practice Decline with Conscientiousness Among Women ( $90 \%$ confidence intervals)

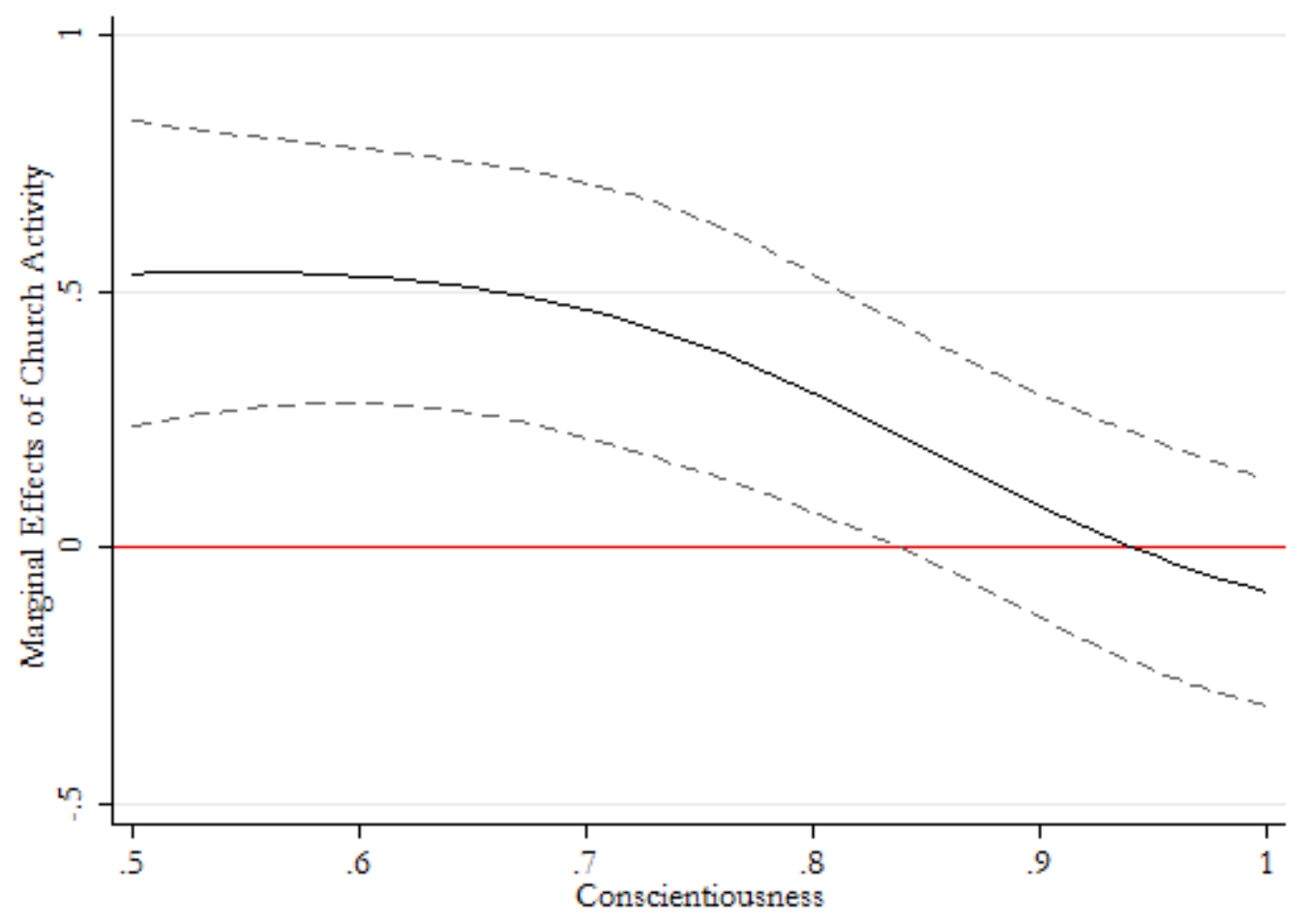

Note: Estimates from Table 2. 
Figure 4-The Marginal Effect of Church Activity Among Women by Conscientiousness at Different Levels of Religious Guidance
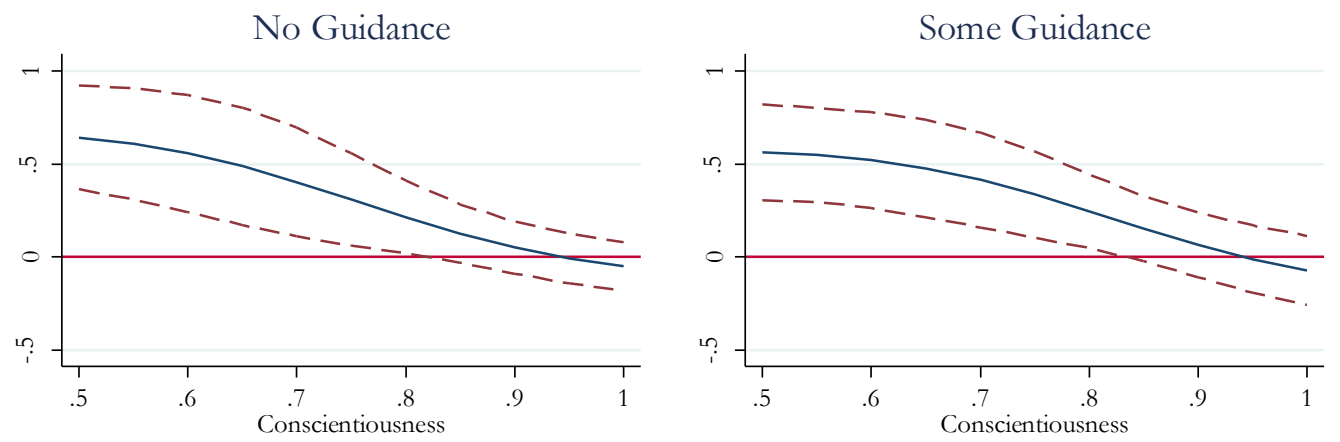

Quite a Bit of Guidance
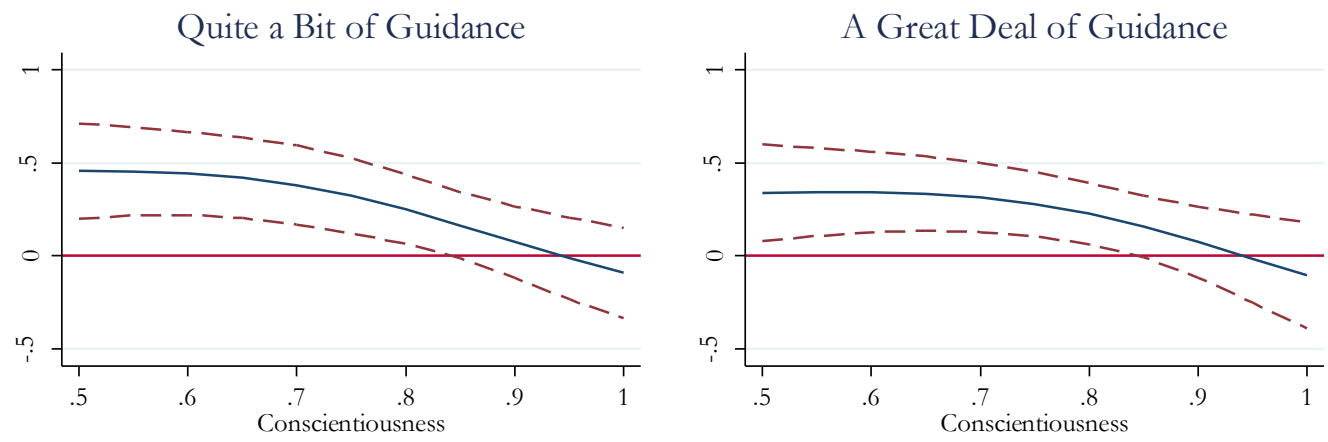